\title{
History of Spine Deformity in Turkey
}

\author{
Sait NADERI', Gulten DINC² \\ ${ }^{1}$ University of Health Sciences, Umraniye Teaching and Research Hospital, Department of Neurosurgery, Istanbul, Turkey \\ ${ }^{2}$ Istanbul University, Cerrahpasa Faculty of Medicine, Department of History of Medicine and Ethics, Istanbul, Turkey
}

\section{ABSTRACT}

Spine deformities are among the most important spinal disorders, affecting health-related life quality. Although there are some studies in past centuries, most spine deformity-related studies and research has started in the last century. Many surgical techniques, performed between 1960 and 1990, made scoliosis a touchable pathology. These techniques started with Harrington's system, wiring techniques, pedicle screw techniques, and all other universal techniques. Anterior and 360 degree techniques contributed to this process. The use of spinal osteotomies, and recent technologies such as magnetic rods, intraoperative neuromonitoring added much to the body of knowledge of literature and improved the outcome. Advancement has not been limited to surgery only and diagnostic advancements had also impact to this process. Surgical techniques performed in the west have been performed soon in our countries. Currently almost all surgical techniques for treatment of spine deformities can be performed in our country. This article reviews historical aspects related to the diagnosis and treatment of spine deformities in Turkey.

KEYWORDS: History of medicine, Kyphosis, Scoliosis, Spine deformity

\section{INTRODUCTION}

$\mathrm{S}$ pine deformities are among the major pathologies that affect human health. Although the contemporary treatment method for this disease started to take shape in the $20^{\text {th }}$ century, knowledge on the subject has a long past in which Anatolian physicians play a prominent role.

We come across Hippocrates of Kos (460-370 BC) as the first physician to treat spine deformities. In his work, "On the Nature of Bones", Hippocrates defined spinal anatomy and spine deformities, describing treatment by axial traction and direct pressure on the deformity $(54,64)$. Galen of Pergamum (129-201 AD), the Roman physician, gathered spinal deformity under four main headings, namely kyphosis, lordosis, scoliosis and spinal joint mobility without deformity (65). He also described the spine and the spinal nerves in further detail.

It is understood from his famous work "Cerrahiyetü'l Haniyye" (Imperial Surgery) written in the late $15^{\text {th }}$ century that Ottoman physician Şerefeddin Sabuncuoğlu applied cauterisation for lumbar pain (68). In fact, this work is an illustrated translation into the Ottoman language of Andalusian physician Al
Zahrawi's book on surgery written in Arabic. Other than these, as in the rest of the world, no treatment for scoliosis worth mentioning can be found in our civilisation at that time. Indeed, it is known that in the $16^{\text {th }}$ century, Suleiman the Magnificent's son Prince Cihangir (1531-1553) had a spine deformity which could not be treated.

Although the first modern school of medicine in the Ottoman Empire was founded 14 March 1827, contemporary western surgical approaches were only able to develop by the late $19^{\text {th }}$ century. The first laminectomy in our country was performed in the late $19^{\text {th }}$ century, but no procedures were attempted to treat scoliosis. The Ankara, Istanbul and Ege Universities played a pioneering role in scoliosis cases. It is likely that conservative procedures were performed to manage scoliosis at the Baltalimanı Bone and Joint Hospital founded in 1944 and the Eğirdir Bone and Joint Hospital founded in 1952.

\section{CONSERVATIVE TREATMENT}

The first treatment approaches with respect to scoliosis were in the form of exercises, physical therapy and casting. 
However, no information is available on the date and method of the first casting and orthosis procedure. What is known is that Prof. Dr. Rieder Pascha, the first director of the Gülhane School of Medicine, founded in 1898, fell and broke his back and leg while inspecting the construction site of the Haydarpasa Faculty of Medicine, which led to the opening of the first orthosis-prosthesis workshop. This first workshop was founded by Hüseyin Bey and Rifat Bey under the name "Tersane-i Alat-ı Nazikiye" (Workshop for Fine Tools), and was incorporated into Gülhane in 1914 (13). This workshop was followed by other public and private workshops, and orthoses were made for scoliosis patients.

The statistics section of Gülhane-Festschrift written by Wieting Pascha (Figure 1) mentions, along with many statistics, that

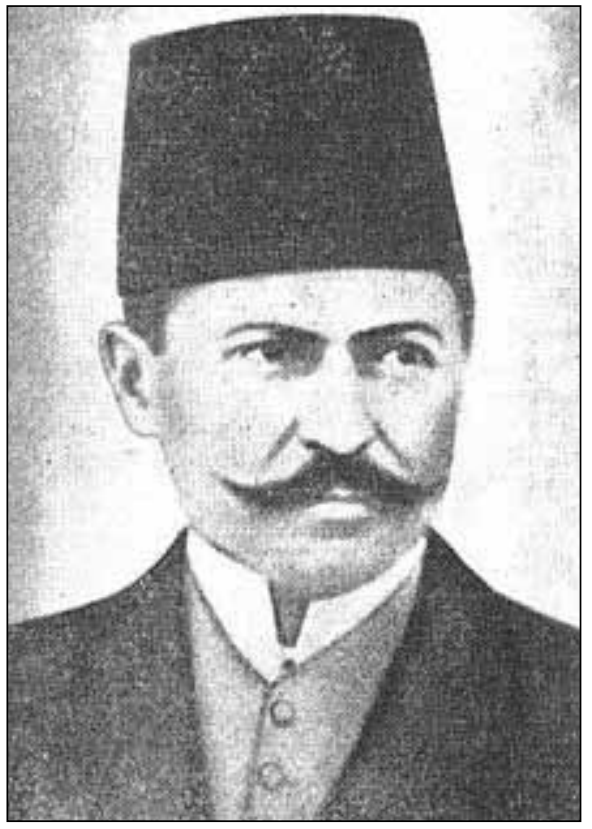

Figure 1: Wieting Pascha.
3 scoliosis patients underwent laminectomy in the previous year. The book also contains a case presentation under the title "congenital scoliosis" (88). This section of the book is one of the first writings on scoliosis in our country (Figures 2 A and $\mathrm{B}$ ).

Similarly, a French medical journal published in Istanbul in those days reported a scoliosis case that was treated through gymnastics (77).

The first corrective-tractive cast (turn buckle cast) in the world was used in the 1920s, and Hibbs, Risser and Ferguson published a series comprising 360 patients in 1931 (53). Risser modified this cast in 1955 (79). No article on this subject dating to the 1940s and 1950s is found in our country. The only related study is from 1960 where Alpsoy (Figure 3) reports cases in which the Risser cast was used (10). In 1962 Alpsoy attended the German Orthopaedic congress held in Munich, where he presented a report on scoliosis, and in 1963 he presented the results of 25 scoliosis cases treated using the Milwaukee corset, which he monitored for a period of 5 years (Figure 4) (11).

\section{THE FUSION ERA}

The world's first spinal fusion procedures were performed in 1911 (6,52), while the first operation of this kind to be carried out in Turkey was performed in 1925 by Mim Kemal Öke (Figure 5) (59). Burhanettin Toker also performed a fusion procedure in 1926 (20). These two fusion cases involved the fusion techniques described by Albee, and were performed spinal infection cases. However, this procedure remained sporadic as well as being mostly performed for tuberculosis (67). In the early 1960 s, modifications of the Albee procedure were performed both for tuberculosis cases and for traumas and deformities. These procedures were performed by Dr. Baha Oskay at Baltalimanı Bone and Joint Hospital, Dr. Orhan Aslanoğlu at Eğirdir Bone and Joint Hospital and Dr. Rıdvan

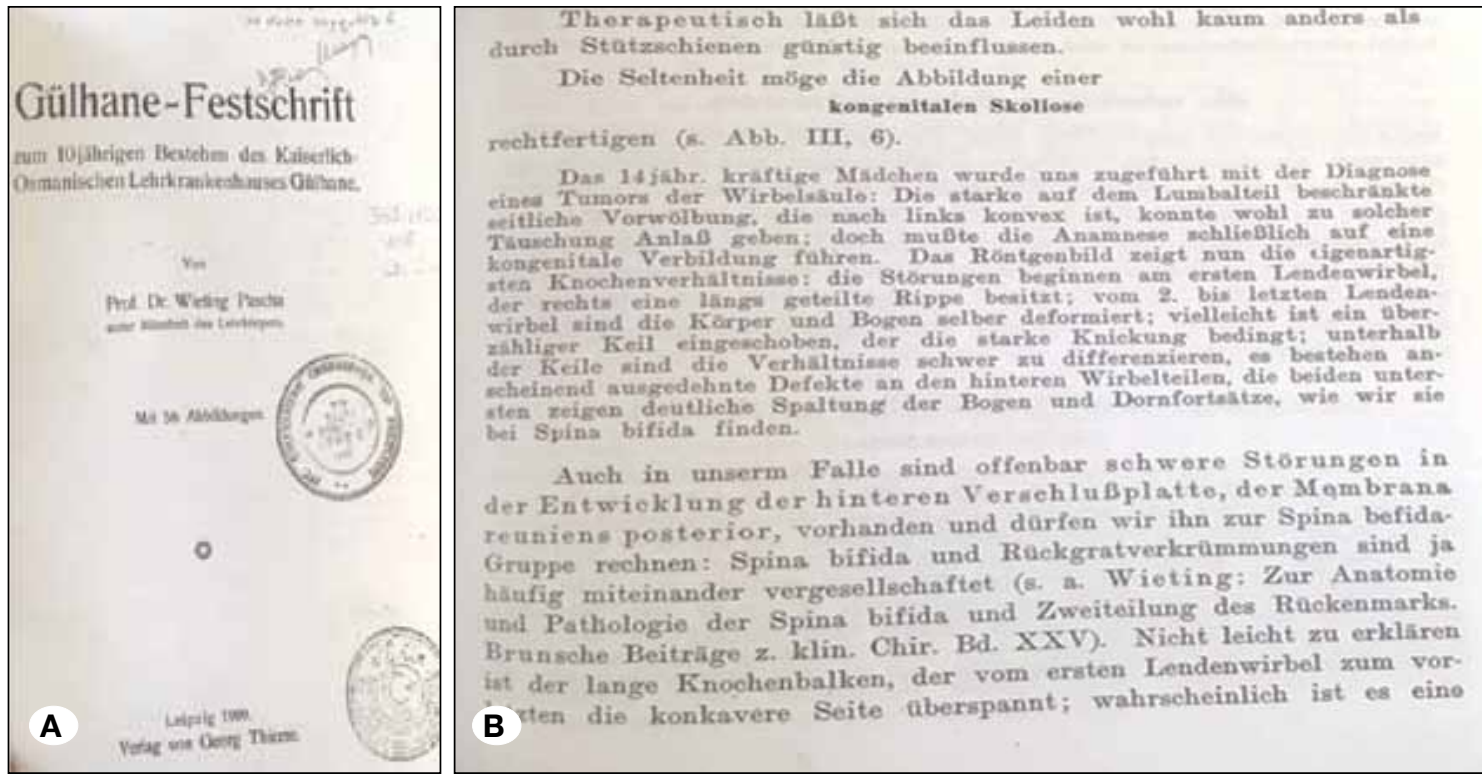

Figure 2:

A) Inner cover of the work GülhaneFestschrift. B) Book section entitled congenital scoliosis. 
Ege at Ankara Gülhane Military Medical Academy Hospital $(39,40,67,72)$. In his 1960 article entitled «new views on the treatment of scoliosis," Cevat Alpsoy indicated that the contemporary treatment for scoliosis was "corrective casting and fusion", recommending that "spine deformities should be especially checked during school health examinations" (10). In 1965 at Ankara Gülhane, Rıdvan Ege performed the first anterior fusion procedure in a spinal tuberculosis case (40).

\section{- THE HARRINGTON-LUQUE PERIOD}

Harrington performed the procedure, which would subsequently be named after him, for the first time in 1958, publishing his first series in 1962 (51). The first surgical procedures for scoliosis in our country were carried out by Prof. Dr. Güngör Sami Çakırgil (Figure 6), Prof. Dr. Bahattin Oğuz Temuçin (Figure 7) and Prof. Dr. Yücel Tümer. The first Harrington-type instrumentation was made by Dr. Güngör

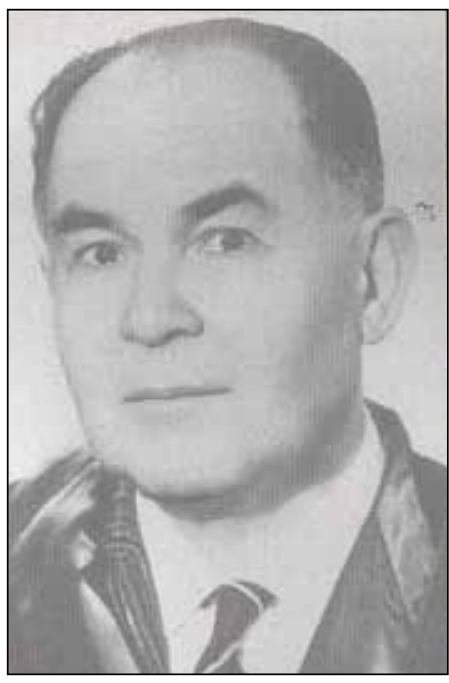

Figure 3: Dr. Cevat Alpsoy.

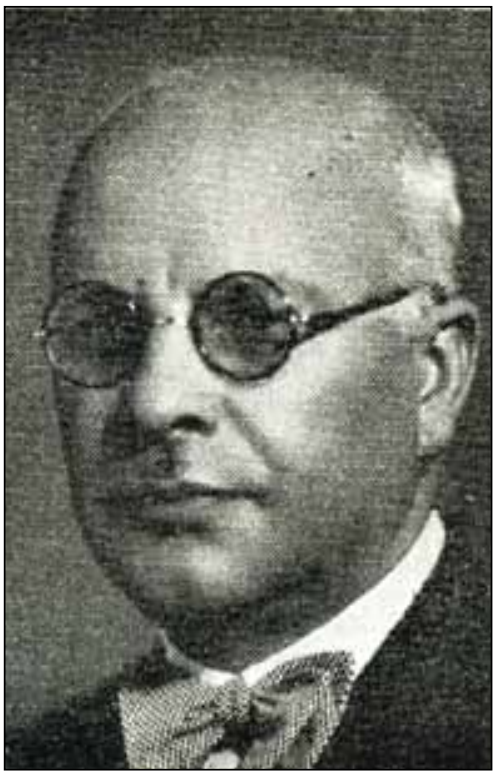

Figure 5: Dr. Mim Kemal Öke.
Sami Çakırgil in 1969 in Ankara. In 1985 Çakırgil reported 585 scoliosis cases operated on between 1969 and 1985 (24).

Subsequently, use of the Harrington procedure started at other centres too (34). By the end of 1969, Dr. Hüsamettin Altav operated on four scoliosis cases in Istanbul (12). Following these first cases, Harrington procedures were performed in

\section{MILWAUKRE KORSESI VE KLINIKTEKI TATBIKATLML}

$$
\begin{aligned}
& \text { MHOF. Dik. CEVAT ALPSOT } \\
& \text { tstanbut Onivernites: }
\end{aligned}
$$

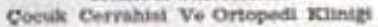

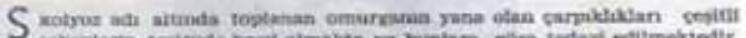

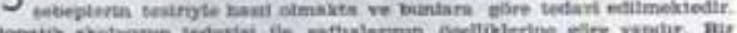

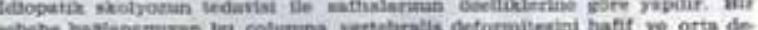

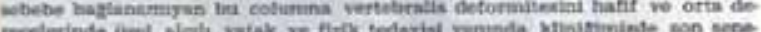

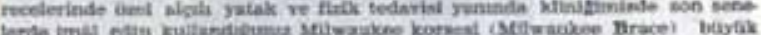

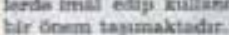

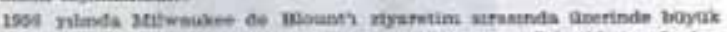

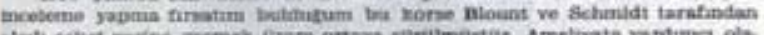

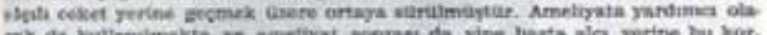

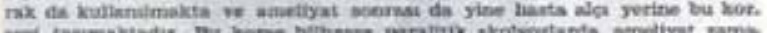

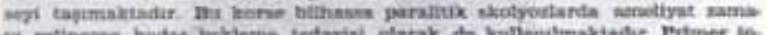

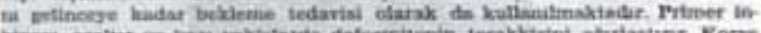

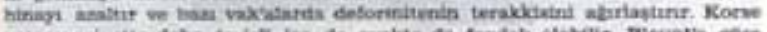

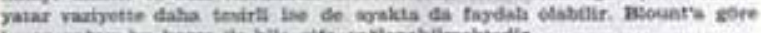

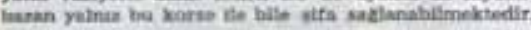

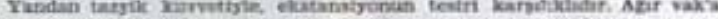

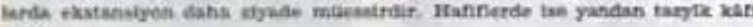
metipor.

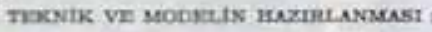

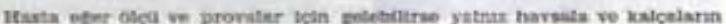

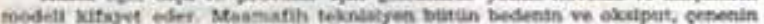

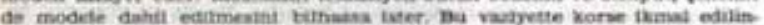

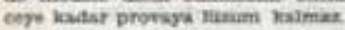

Tan bedes modell mpensx kith hasts bsyindan avitr, tsteniten derece

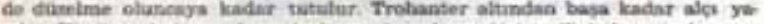

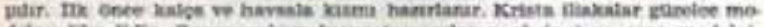

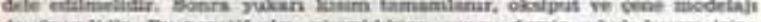

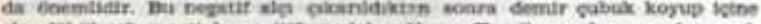

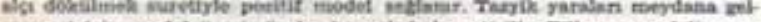

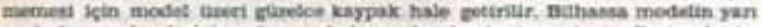

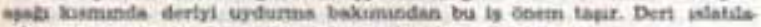

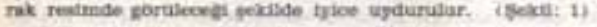

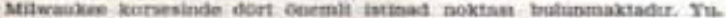

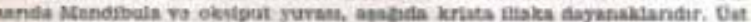

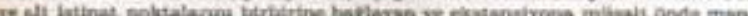

Figure 4: Dr. Alpsoy's article.

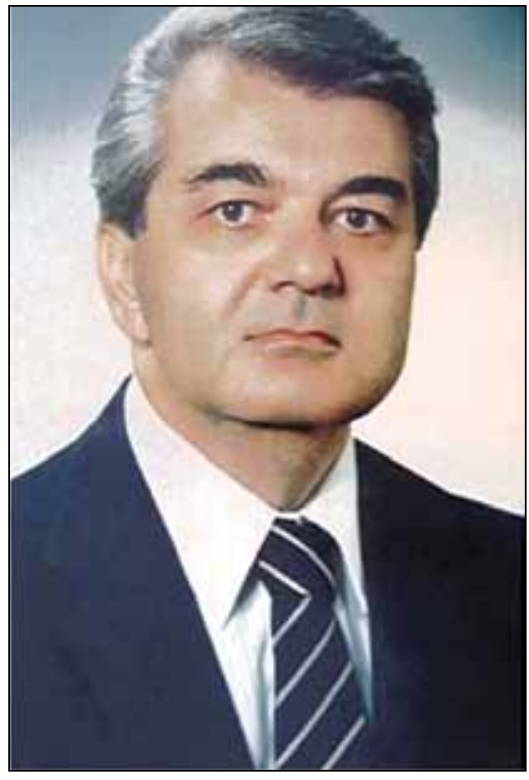

Figure 6: Dr. Güngör Sami Çakırgil. 


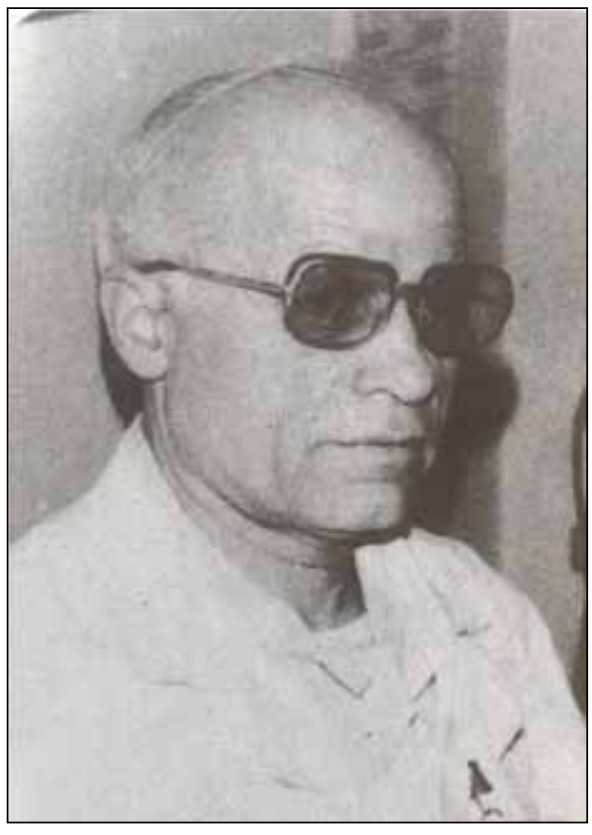

Figure 7: Dr. Bahattin Oğuz Temoçin.

1970 in Istanbul by Dr. Temoçin, in 1972 in Izmir by Dr. Mehmet Tiner and in 1974 at Hacettepe by Dr. Nejat Tokgözoğlu (Personal communication with Dr. Adil Surat on 15.08.2016) (85). The first Harrington Cotrel procedure was performed by Dr. Yücel Tümer in 1981 (Personal communication with Dr. Yücel Tümer on 03.08.2016).

The first sublaminar wiring for scoliosis was reported by Luque in 1982 (63), and this operation was performed for the first time in Turkey by Dr. Nafiz Birsel in 1989 at the Hospital of Cerrahpaşa School of Medicine (18).

The Drummond technique was applied for the first time in 1987 by Dr. Azmi Hamzaoğlu (50). In 1989 Dr. Çakırgil reported the results of the Harrington-Luque procedures (26).

\section{THE PEDICLE SCREW ERA}

When it was found in the 1980s that scoliotic deformity is three-dimensional, third-generation instrumentation systems (Cotrel-Dubousset, TSRH, Isola) allowing correction on the coronal, sagittal and axial planes were developed $(43,56,66)$. Although the first pedicle screw was developed in 1959 by Boucher, it had not seen widespread application (19). From 1963, Roy-Camille fixed the screws inserted into the pedicle using a plate, publishing his first results in 1970 (80). Interest in pedicle screws increased following that article.

The first results of the Cotrel-Dubousset system, which is one of these third-generation instrumentation systems, were published for the first time in 1988, which earned the system popularity in a short space of time (22).

In our country, the first pedicle screw was applied in the 1980s. This first procedure was performed using Schanz screws. The first pedicle Schanz screw was made in 1988 after the AO course held in İzmir, by Dr. Derya Dinçer and Dr. Illker Çetin from Ankara University, after receiving training from the Swiss Walter Dick, the designer of the system (Personal communication with Dr. Derya Dinçer on 02.08.2016) (33). The same procedure was performed towards the end of 1988 by Dr. Mazhar Tokgözoğlu and Dr. Haluk Berk from Hacettepe University, and by Dr. Osman Güven in Istanbul (Personal communication with Dr. Derya Dinçer and Dr. Haluk Berk on 02.08.2016).

The first pedicle screw applications under the CD system were performed in November 1988 by Dr. Ömer Çeliker $(29,30,40)$ in Ankara and by Dr. Ünsal Domaniç in Istanbul, almost on the same dates $(35,36)$ (Personal communication with Dr. Teoman Benli, Dr. Osman Güven and Dr. Derya Dinçer on 02.08.2016, Dr. Ünsal Domaniç on 03.08.2016, and Mr. Mehmet Elestekin on 02.08.2016). After this, the CD operation became widespread, being performed in 1989 by Dr. İlker Çetin in Ankara (31) and by Dr. Osman Güven in Istanbul (Personal communication with Dr. Osman Güven on 02.08.2016).

The first stabilisation using TSRH was performed in 1991 at the Dışkapı SSK Hospital by Dr. Teoman Benli and Dr. Mert Tüzüner (Personal communication with Dr. Benli on 02.08.2016). From 1997 Dr. Cüneyt Şar regularly used reduction screws for sagittal deformities (Personal communication with Dr. Cüneyt Şar on 11.08.2016).

\section{- ANTERIOR PROCEDURES}

In 1964, Allen Dwyer described the anterior approach in scoliosis treatment, claiming that this approach would ensure correction with less construction (38). In the following years anterior procedures were carried out using different rods, wires and cables, which were subsequently combined with posterior procedures.

The first anterior fusion related to spinal infections in our country was performed by Dr. Güngör Sami Çakırgil (25), and the first procedures for scoliosis cases were performed subsequently. Anterior surgery in scoliosis was performed in Turkey for the first time in 1972 by Dr. Güngör Sami Çakırgil, who returned to Turkey after completing his education in Hong Kong (Personal communication with Dr. Orhan Girgin on 05.08.2016). From 1974, anterior procedures have been performed regularly by Dr. Emin Alıcı in İzmir and later by Dr. Ünsal Domaniç in Istanbul (Personal communication with Dr. Ünsal Domaniç on 03.08.2016). Following its first performance in 1976 in Germany, the Zielke procedure for idiopathic scoliosis (anterior instrumentation and correction) (94) was performed in our country in 1991 by Dr. Azmi Hamzaoğlu. The first thoracoscopic deformity surgery aimed at relaxation was performed in 1993 by Dr. Emin Alıcı, while the first thoracoscopic screw application was carried out in 1994, again by Dr. Emin Alıcı $(8,9)$. In the surgical treatment of scoliosis, selective anterior thoracic fusion in dual deformities was first performed by Dr. Azmi Hamzaoğlu in 1994 (Personal communication with Dr. Azmi Hamzaoğlu on 10.08.2016).

\section{COMBINED PROCEDURES}

Combined procedures started in the 1980s. From 1989, Dr. Gülşen performed combined anterior and posterior procedures 
on selected cases $(47,49)$. Again from 1989, combined procedures had been applied by Dr. Benli to the Scheuermann kyphosis in Ankara Dışkapı (17). Combined procedures on rigid cases were also reported by Dr. Şükrü Solak and his colleagues from 1991 (82). Dr. Amzi Hamzaoğlu performed combined anterior and posterior surgery in scoliosis surgery (anterior discectomy+release+fusion+posterior instrumentation and correction using 1st generation CD) in 1990 and a combined anterior-posterior convex hemiepiphysiodesis procedure in 1991 (Personal communication with Dr. Azmi Hamzaoğlu on 10.08.2016).

\section{- OSTEOTOMIES}

Osteotomies in spine deformities started to be performed in our country in the 1960s. The first procedures on kyphotic deformities were performed by Dr. Orhan Aslanoğlu (Figure 8) in 1961, and this study was published in 1963 (14). In $1971 \mathrm{Dr}$. Ali Akçiçek (Figure 9) presented 53 kyphosis cases on which he performed vertebral Herbert osteotomy (Figure 10) (3). In scoliosis, however, a rigid osteotomy was performed for the first time in 1990 by Dr. Ünsal Domaniç under the name "total wedge resection (Domaniç) osteotomy." In 2004, Domaniç et al. published the results of the 32 cases on which they operated between 1990 and 2000 (37).

In 1990, anterior multiple osteotomy+posterior osteotomy and correction of congenital lordoscoliosis was performed by Dr. Azmi Hamzaoğlu. In 1992 anterior-posterior combined hemivertebra resection was also performed for the first time by Dr. Azmi Hamzaoğlu (Personal communication with Dr. Azmi Hamzaoğlu on 10.08.2016).

Dr. Mahir Gülşen performed the first eggshell osteotomy in 1991, which he published in 1992. Later, he applied the same method to the cervical spine in cases of ankylosing spondylitis (45-48).

Posterior hemivertebra resection (1994), the application of Posterior Vertebral Column Resection (PVCR) (1997) in the surgical treatment of advanced spine deformities, and Ponte osteotomy (1998) applications in the surgical treatment of scoliosis were first performed by Dr. Azmi Hamzaoğlu (Personal communication with Dr. Azmi Hamzaoğlu on 10.08.2016).

\section{- OTHER DEVELOPMENTS}

In 1991, Dr. Azmi Hamzaoğlu became the first in the world and in Turkey to use a traction film under general anaesthesia and intraoperative traction in assessing scoliosis (Personal communication with Dr. Azmi Hamzaoğlu on 10.08.2016).

The wakeup test was performed for the first time in our country in 1989 by Dr. Nafiz Bilsel (Personal communication with Dr. Nafiz Birsel on 03.08.2016). Intraoperative neuromonitoring, however, was performed for the first time in 1989 at Gülhane Military Medical Academy Hospital by Dr. Kaplan and his colleagues (58). In this study Kaplan and his colleagues performed neuromonitoring using a somatosensory evoked potential during scoliosis surgery. A similar application was carried out in 1991 at Dokuz Eylül University. The first neuromonitoring using motor evoked potential was performed in 2003 by Dr. Azmi Hamzaoğlu (Personal communication with Dr. Azmi Hamzaoğlu on 10.08.2016).

The extreme lateral interbody fusion (XLIF) application in scoliosis surgery was first performed in 2008 by Dr. Azmi Hamzaoğlu, was then applied by Dr. Cüneyt Şar at Istanbul University, and is now increasingly being performed at many

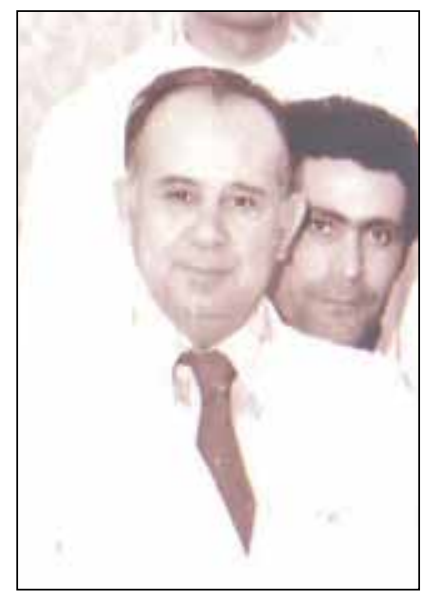

Figure 8: Dr. Orhan Aslanoğlu.

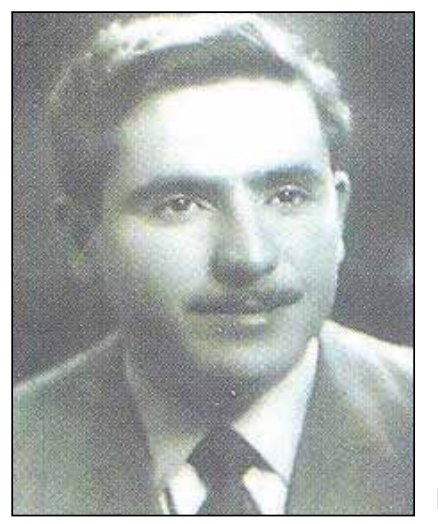

Figure 9: Dr. Ali Akçiçek.

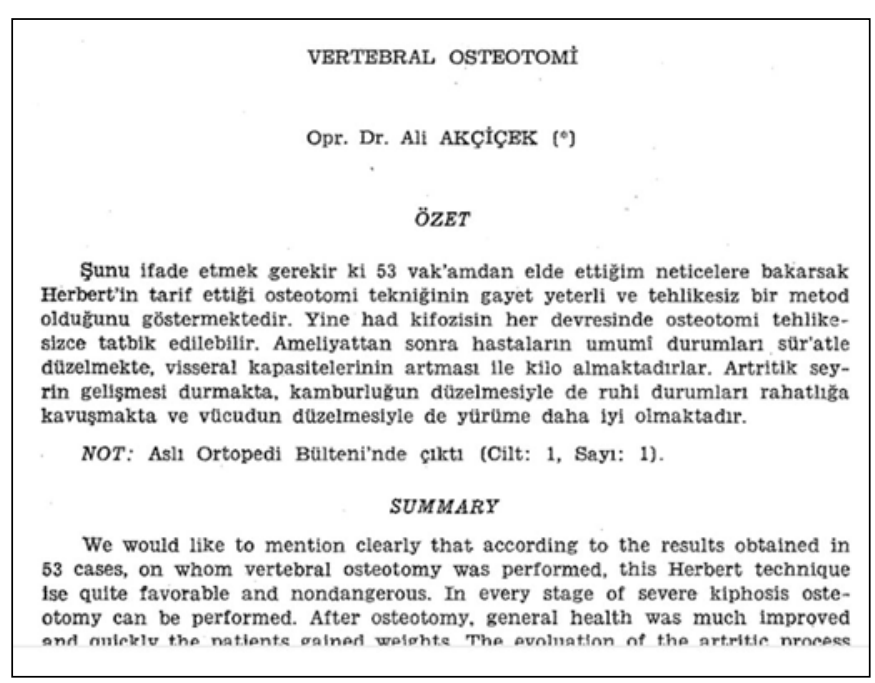

Figure 10: Title of Dr. Akçiçek's article. 
centres (Personal communication with Mr. Kaşif Alp Seval).

Stabilisation with magnetically-controlled growing rods was first applied in 2010 by Dr. Muharrem Yazıcı (Personal communication with Mr. Sinan Kazmacı).

In recent years neurosurgeons have also started to tend to perform spinal surgery. Neurosurgeons, who actually played a pioneering role in degenerative and cervical spine surgery, started to show interest in thoracolumbar instrumentation in the late 1980s, the first studies being published in 1989 (78). In the 1990s, spinal instrumentation was applied to many pathologies $(69,81)$. From the mid-1990s, neurosurgeons performed procedures chiefly in thoracolumbar trauma and lumbar degenerative scoliosis. The first paediatric scoliosis procedure was performed in 1996 by Dr. Zileli (Personal communication with Dr. Zileli on 16.08.2016). Especially in recent years, complex instrumentation and osteotomies have been performed on paediatric and adult scoliosis and kyphosis cases at many neurosurgery centres $(5,15,23,27,28,41,42,58,61,73,74,89-92,95)$. Many spine deformity courses are held due to the interest in spine deformity, and physicians become members of associations such as the Scoliosis Research Society, participating in studies.

\section{SCOLIOSIS SCREENING}

The first scoliosis screening in our country was performed in 1982 by Sirrı Aksu for a dissertation study (4). In the 2000s, similar studies were seen to be performed at province and district level $(1,16,21,44,55,60,75,76,84,86,93)$.

\section{PUBLICATIONS ON SPINE DEFORMITIES}

In our country, over 40 dissertations have been written on scoliosis and other spine deformities. Most of these comprise clinical research.

In the last 50 years, 77 books were published in our country on spinal health and diseases (70). Three of these books are on spinal deformities. These are Omurga hastalıkları ve deformiteleri (Spinal Diseases and Deformities) by Prof. Dr. Emin Alıcı (1991) (Figure 11A) (7), Spinal deformiteler (Spinal Deformities) by Dalbayrak et al. (2015) (Figures 11 A,B) (32), and Omurganın sagittal plan deformiteleri (Sagittal Plane Deformities of the Spine) (2016) published by Üzümcügil et al. (Figure 11 C) (87). There are also three books, one translated from Lehnert-Schroth's English book by Dr. Gülseren Kayalar entitled as Skolyozun üç boyutlu tedavisi (Three-dimensional treatment of scoliosis) (62) (Figure 12A), and two English books, one edited by Akbarnia, Yazıcl, and Thompson, The growing spine (2) (Figure 12B), and other edited by YazıcI, Non-idiopathic scoliosis in young children (91) (Figure 12C). Other than these academic works, iffet Oral and Nazan Özen published a children's book titled Skolyoz (Scoliosis) in a children's stories series (71) (Figure 13). Finally, the Turkish Spine Society is currently preparing a book titled Iddyopatik skolyoz (Idiopathic Scoliosis) for publication in 2017.

\section{AFTERWORD}

Spine deformities cause serious health problems, but in the meanwhile new treatment methods are being developed. It is observed that Turkish surgeons follow developments in the world in deformity surgery, and that the techniques developed are applied in our country without delay. It is understood that our surgeons have recently been playing a pioneering role in spine deformities as in all secondary branches of spinal surgery.
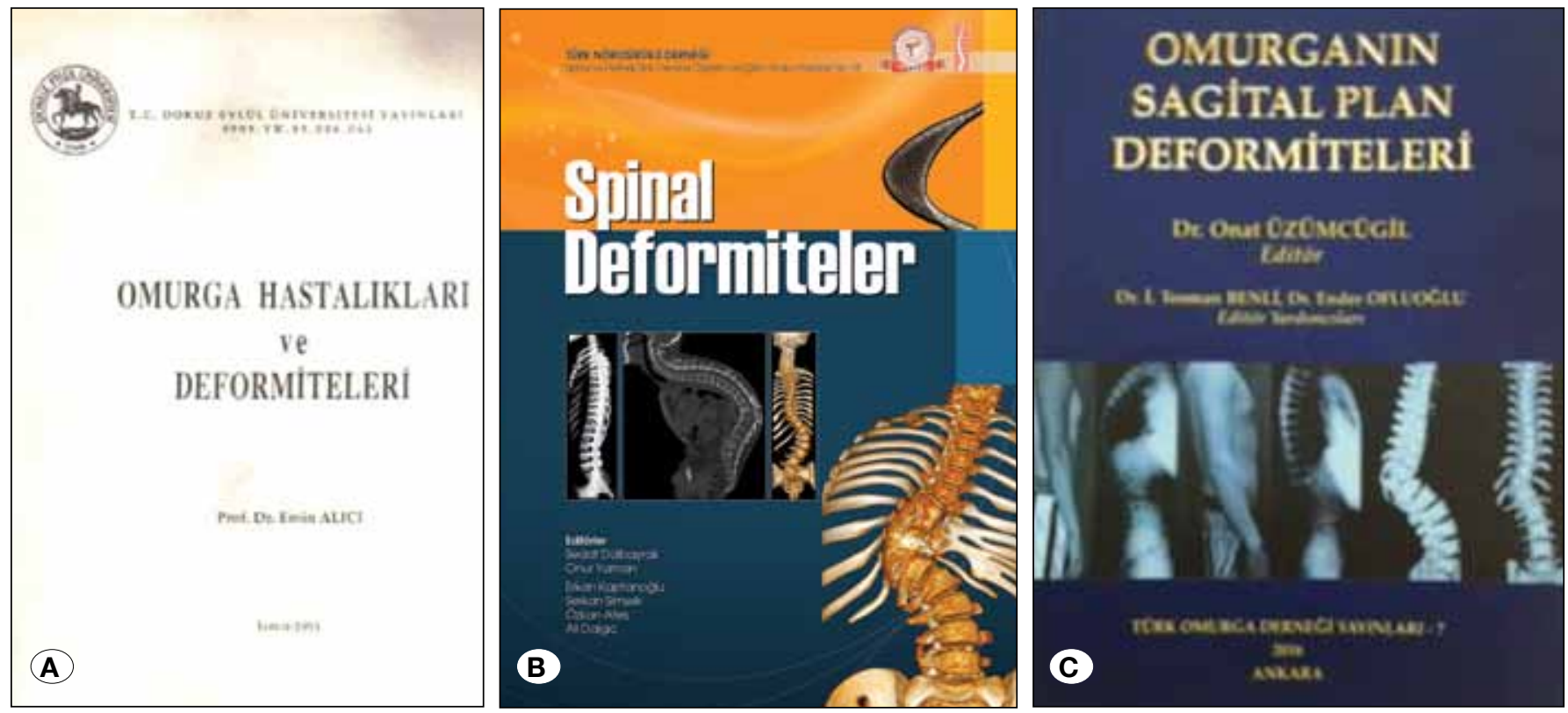

Figure 11: A) Cover of Dr. Emin Alıcı's book (Spinal diseases and deformities), B) cover of the book edited by Dalbayrak et al. (Spinal deformities), C) "cover of the book edited by Üzümcügil et al. (Sagittal plane deformities of the spine). 

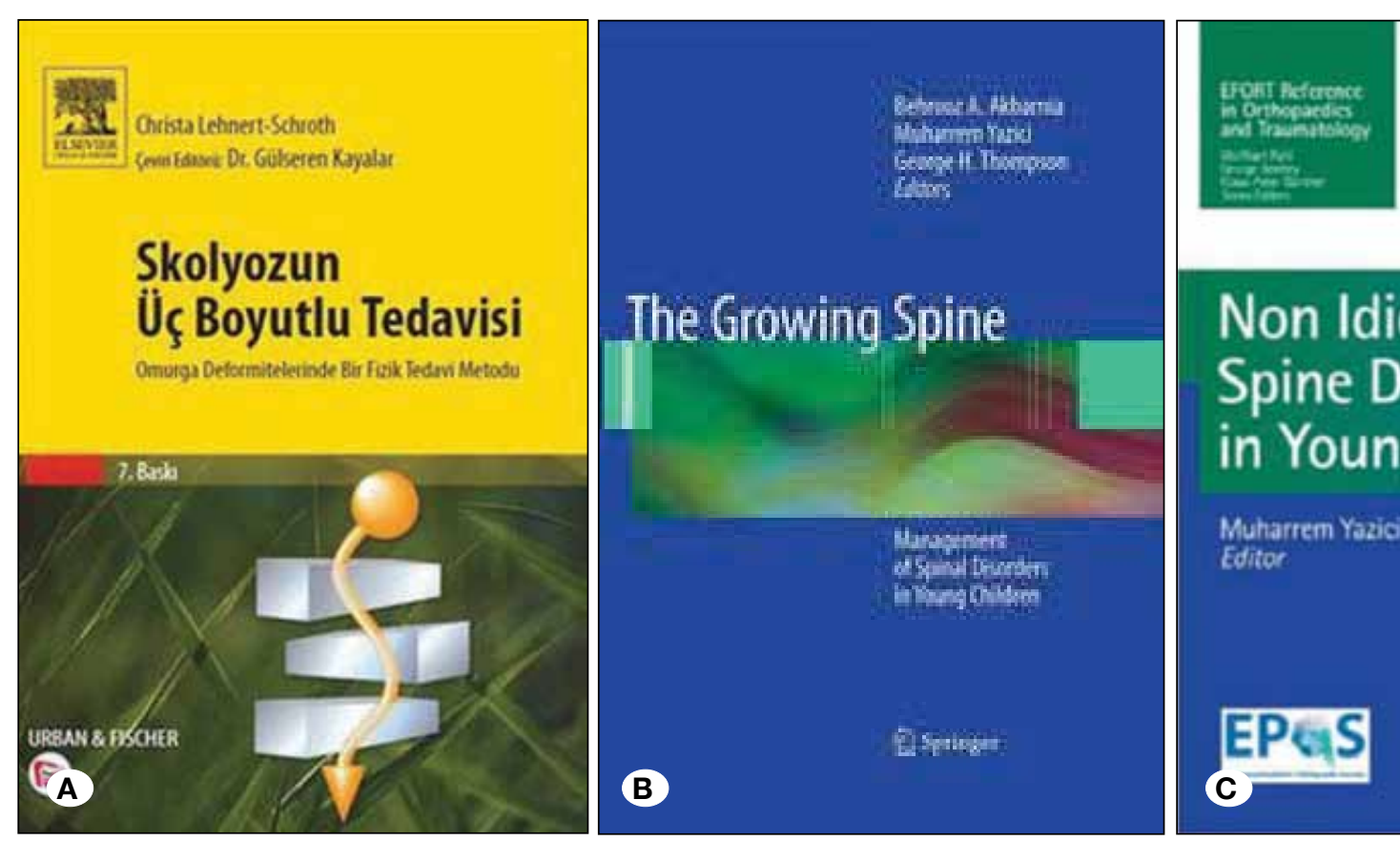

Non Idiopathic Spine Deformities in Young Children

Muharrem Yozid

Editor

Figure 12: A) Cover of the book translated by Kayalar (Three-dimensional treatment of scoliosis), B) cover of "The Growing Spine" edited by Akbarnia, Yazıcı and Thompson, and C) cover of "Non-Idiopathic Scoliosis in Young Children" edited by Dr. Muharrem Yazıcı.

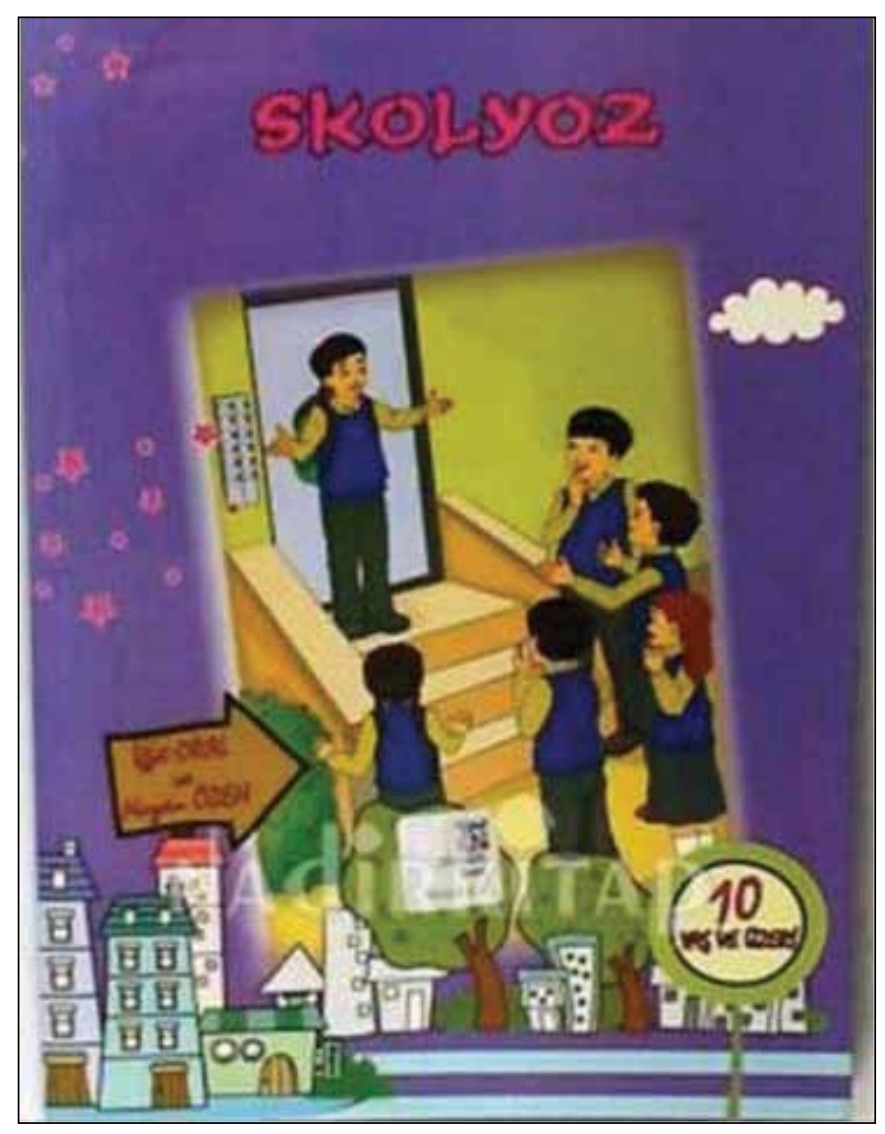

Figure 13: Cover of children's book written by iffet Oral and Nazan Özen (Scoliosis).

\section{ACKNOWLEDGEMENTS}

We wish to thank the following, from whose work we benefitted during this study:

Dr. Ömer Akçalı, Dr. Emin Alıcı, Dr. Teoman Benli, Dr. Haluk Berk, Dr. Nafiz Bilsel, Dr. Derya Dinçer, Dr. Ünsal Domaniç, Dr. Mahir Gülşen, Dr. Osman Güven, Dr. Azmi Hamzaoğlu, Dr. İbrahim Örnek, Dr. Adil Surat, Dr. Cüneyt Şar, and company officials Mr. Mehmet Elestekin, Mr. Sinan Kazmacı and Mr. Kaşif Alp Seval.

\section{REFERENCES}

1. Adak B, Önen MŞ, Tekeoğlu I, Arslan A: Van ili merkez ilköğretim okullarında skolyoz taraması. Scoliosis Screening at Van Province Central Primary Schools. Türkiye Fiziksel Tıp ve Rehabilitasyon Dergisi 2:45-49, 1999 (In Turkish)

2. Akbarnia BA, Yazıcı M, Thompson GH: The Growing Spine. Management of Spinal Disorders in Young Children. Berlin: Heidelberg, Springer, 2011

3. Akçiçek A: Vertebral osteotomilerinin bugünkü ortopedideki yeri [The place of vertebral osteotomies in today's orthopaedics]. 2. Milli Türk Ortopedi ve Travmatoloji kongresi, İstanbul, 27-30 Mayıs 1971: 102 (In Turkish)

4. Aksu S: Kayseri ili merkeze bağlı ilk ve orta dereceli okul çocuklarında skolyoz prevelansı [Scoliosis prevalence in primary and secondary school students in central Kayseri]. Kayseri, Erciyes Üniversitesi Tıp Fakültesi Tıpta Uzmanlık Tezi, 1982 (In Turkish)

5. Akyuva Y, Çakır CÖ, Reşitoğlu G, Çaylı SR: Arnold Chiari malformasyonu ve skolyoz birlikteliği; 4 olgu sunumu [Concomitance of the Arnold Chiari malformation and scoliosis; presentation of 4 cases]. Türk Nöroşirürji Dergisi 23 (Ek Sayı): 133, 2013 (In Turkish) 
6. Albee FH: Transplantation of a portion of the tibia into the spine for Pott's disease. A preliminary report. JAMA 57: 885886, 1911

7. Alıcı E: Omurga hastalıkları ve deformiteleri [Spine diseases and deformities]. İzmir, Dokuz Eylül Üniversitesi Yayınları, 1991 (In Turkish)

8. Alıcı E, Berk H, Özkara M: Thoracoscopic anterior applications to the spine. Presented in III. International congress on spine surgery in Turkey, Antalya, October 2-6, 1994

9. Alıcı E, Berk H, Özkara M, Yaldız K: Thoracoscopic anterior applications to the spine. Eurospine 96. Zürich, Switzerland, 16-19 October 1996

10. Alpsoy C: Skolyoz tedavisinde yeni görüşler [New views on scoliosis treatment]. 16. Milli Türk Tıp Kongresi, Ankara, 26-29 Eylül 1960: 248-272 (In Turkish)

11. Alpsoy C: Milwaukee korsesi ve klinikteki tatbikatımız [The Milwaukee corset and our clinical application]. Acta Orthop Traumatolog Turc 1: 27-32, 1963 (In Turkish)

12. Altav H: Harrington metodu ile Scolios'da korreksiyon ve içten fixation [Correction and internal fixation of Scoliosis using the Harrington method]. 2. Milli Türk Ortopedi ve Travmatoloji Kongresi, İstanbul, 27-30 mayıs 1971: 103-105 (In Turkish)

13. Anonim: Türkiye'de ortez protezin alanının tarihsel gelişimi [Anonymous. The historic development in the field of orthoses and prostheses in Turkey]. http://www.turkprot.org/turkiyedeprotez-ortez-alaninin-tarihsel-gelisimi,2,29 (Accessed August 08, 2016). (In Turkish)

14. Aslanoğlu O: Spondilit ankilozanda osteotomi vertebral [Vertebral osteotomy in ankylosing spondylitis]. Acta Orthop Traumatol Turc 2: 33-37, 1963 (In Turkish)

15. Ateş Ö, Çaylı SR, Çakır CÖ, Durak, MA, Ateş A, Koçak A, Öztürk E: Konjenital torakolomber kifotik deformitelerde posterior kama osteotomi cerrahi tekniğinin sonuçları [Results of the posterior wedge osteotomy surgical technique in congenital thoracolumbar kyphotic deformities]. Türk Nöroşirürji Derneği XXI. Bilimsel Kongresi, Antalya, 20-24 Nisan, 2007 (In Turkish)

16. Bayık Temel A, İnci FH, Harputlu D, Emlek Sert Z: Türkiye'de okul-tabanlı skolyoz tarama programının sonuçları [Results of the school-based scoliosis screening programme in Turkey]. TAF Preventive Medicine Bulletin 14: 202-208, 2015 (In Turkish)

17. Benli T, Kaya A: The outcome of anterior release, posterior instrumentation and circumferential fusion in Scheuerman kyphosis. J Turk Spinal Surg 17: 1-8, 2006

18. Bilsel N: Vertebra kırıklarının tedavisinde SSI metodu [The SSI method in the treatment of vertebra fractures]. 11. Milli Türk Ortopedi ve Travmatoloji Kongresi, Ankara, 27-30 Eylül 1989: 81-84 (In Turkish)

19. Boucher $\mathrm{HH}$ : A method of spinal fusion. J Bone Joint Surg 41B: 248- 259, 1959.

20. Burhaneddin: Spondylite operee par la methode D'Albee. Gazette Medicale D‘orient 71: 1118, 1926 (In French)

21. Cilli K, Tezeren G, Taş T, Bulut O, Öztürk H, Öztemur Z, Ünsaldı T: School screening for scoliosis in Sivas, Turkey. Acta Orthop Traumatol Turc 43: 426-430, 2009
22. Cotrel Y, Dubousset J, Guillaumat M: New universal instrumentation in spinal surgery. Clin Orthop Relat Res 227: 10-23, 1988

23. Çakır CÖ, Çaylı SR: Congenital Scoliosis. Turk Neurosurg 24 29-37, 2013

24. Çakırgil GS: İdiopatik skolyozun ciddi eğriliklerinde Halofemoral traksiyon ve Harrington enstrumantasyonu, spinal füzyonun etkinliği [The effectiveness of Halo-femoral traction and the Harrington instrumentation, spinal fusion in severe curvatures of idiopathic scoliosis]. 11. Milli Türk Ortopedi ve Travmatoloji Kongresi, Alanya, 28-30 Ekim 1985: 272 (In Turkish)

25. Çakırgil GS: Vertebral tüberkülozun tedavisinde vertebrektomi ve anterior füzyon uyguladığımız 50 vakanın değerlendirmesi [Evaluation of 50 cases in which we performed vertebrectomy and anterior fusion in treating vertebral tuberculosis]. Acta Orthop Traumatol Turc 20: 231-244, 1986 (In Turkish)

26. Çakırgil GS, Adıyaman S: Instabil torakolumbar kırıkların konservatif tedavisi ile Harrington ve Harrington-Luque instrumantasyonun mukayeseli bir klinik çalışması [A comparative clinical study of the conservative treatment of unstable thoracolumbar fractures and the Harrington and Harrington-Luque instrumentation]. 11. Milli Türk Ortopedi ve Travmatoloji Kongresi, Ankara, 27-30 Eylül 1989:299-300 (In Turkish)

27. Çaylı SR, Çakır CÖ, Öztanır N, Reşitoğlu R, Akyuva Y: İdiopatik adelosan skolyoz: 2 yıllık deneyim [Idiopathic adolescent scoliosis: a 2-year experience]. Türk Nöroşirürji Dergisi 22 (Ek Sayı): 78, 2012 (In Turkish)

28. Çaylı SR, Çakır CÖ, Öztanır N, Ateş A, Gökçek C, Yardım A: Konjenital deformitelerde olgu yönetimi: 40 olgu deneyimi [Case management in congenital deformities: an experience of 40 cases]. Türk Nöroşirürji Dergisi 22 (Ek Sayı): 56, 2012 (In Turkish)

29. Çeliker Ö, Tüzüner MM, Benli T, Çıtak M: Skolyoz cerrahisinde Cotrel-Dubousset tekniği [The Cotrel-Dubousset technique in scoliosis surgery]. 11. Milli Türk Ortopedi ve Travmatoloji kongresi, Ankara, 27-30 Eylül 1989: 288-290 (In Turkish)

30. Çeliker Ö, Tüzüner M, Benli T: The results of Cotrel Dubosset instrumentation in idiopathic scoliosis. J Turk Spinal Surg 1: 14-18, 1990

31. Çetin I, Dinçer D, Yazar T, Mergen E, Ömeroğlu H: Cotrel Dubousset instrumentation applications. Early results. J Turk Spinal Surg 1: 22-24, 1989

32. Dalbayrak S, Yaman O, Kaptanoğlu E, Şimşek S, Ateş Ö, Dalgıç A: Spinal deformiteler [Spinal deformities]. Ankara, Türk Nöroşirürji Derneği Spinal ve Periferik Sinir Cerrahisi Öğretim ve Eğitim Grubu yayınları No: 18, 2015 (In Turkish)

33. Dinçer D: Torakolomber vertebrak kırıklarında fiksatör intern [Internal fixator in thoracolumbar vertebral fractures]. XI. Milli Türk Ortopedi ve Travmatoloji kongresi, Ankara, 27-30 Eylül 1989, S: 74-76 (In Turkish)

34. Domaniç Ü, Hamzaoğlu A, Temoçin BO, Akalın Y, Taşer O: Harrington Çivileri Kullanılarak Tedavi Edilen Idiopatik Skolyozda Ameliyat Öncesi ve Sonrası Dönemlerde Pulmoner Fonksiyonların Karşılaştııılması [Comparison of Pulmonary Functions in Pre- and Post-operative Terms in Idiopathic Scoliosis Treated Using Harrington Screws]. Acta Orth Trauma Turc18: 185-191, 1984 (In Turkish) 
35. Domaniç Ü, Esenkaya İ, Başkır O: İdiopatik skolyozun cerrahi tedavisinde Cotrel- Dubousset yöntemi ve erken sonuçlarımız [The Cotrel-Dubousset method in the treatment of idiopathic scoliosis and our preliminary results]. XI. Milli Türk Ortopedi ve Travmatoloji Kongresi, Ankara, 27-30 Eylül 1989: 291-295(In Turkish)

36. Domaniç Ü, Esenkaya I, Kaygusuz MA, Şar C: The role of Cotrel Dubousset instrumentation in the surgical treatment of idiopathic scoliosis. J Turkish Spinal Surg 1: 11-13, 1990

37. Domaniç U, Talu U, Dikici F, Hamzaoğlu A: Surgical correction of kyphosis: Posterior wedge resection osteotomy in 32 patients. Acta Orthop Scand. 75: 449-455, 2004

38. Dwyer AF, Newton NC, Sherwood AA: An anterior approach to scoliosis. A preliminary report. Clin Orthop 62: 192- 202, 1969

39. Ege R: Vertebra füzyon (artrodez) ameliyatı ve teknik hususiyetler [Vertebral fusion (arthrodesis) procedure and technical properties]. Gülhane As. Tıp Ak. Bült 7: 19-38, 1962 (In Turkish)

40. Ege R: Tıp tarihinde vertebranın yeri [The place of the vertebra in medical history]. Ege R (editör): Omurga. Ankara, Trafik Hastanesi Yayınları. 1990: 1-13 (In Turkish)

41. Gezercan Y, Arslan A, Ökten Ail, Çıkılı M, Menekşe G, Bilgin E, Uysal İ, Boğa Z: Adolesan skolyoz cerrahisi: 21 Olgu [Adolescent scoliosis surgery: 21 Cases]. Spinal Deformiteler Sempozyumu, Antalya, 29 Ekim-1 Kasım 2015 (In Turkish)

42. Gezercan Y, Ökten Ai, Çıkılı M, Menekşe G, Arslan A, Uysal I, Boğa Z, Açık V, Olmaz B: Spinal deformite cerahisinde osteotomiler: 30 olguluk klinik çalışma [Osteotomies in spinal deformity surgery: A clinical study of 30 cases]. Türk Nöroșirürji Derneği 30. Bilimsel Kongresi, Antalya, 8-12 Nisan 2016. (In Turkish)

43. Good, Christopher R: Evolution in the treatment of spinal deformity and spinal instrumentation. Journal of the spinal research foundation 5: 1-25, 2010

44. Görkem Barış F: Ankara ili Sincan ilçesinde bir ilköğretim okulu ve bir lisede öğrenim gören öğrencilerde skolyoz ve kifoz sıklığının belirlenmesi [Identification of the prevalence of scoliosis and kyphosis in students studying at a primary school and a high school in the Sincan district of Ankara]. Ankara, Gazi Üniversitesi, Sağlık Bilimleri Enstitüsü, Hemşirelik Programı tez çalışması, 2009 (In Turkish)

45. Gülşen M, Özbarlas S, Herdem M, Baytok G: The "Egg Shell" procedure. J Turk Spinal Surg 3: 21-24, 1992

46. Gülşen M, Özbarlas S, Baytok G, Herdem M: Surgical treatment of spinal deformities in ankylosing spondylitis. J Turk Spinal Surg 4: 112-115, 1993

47. Gülşen $M$, Toğrol E, Herdem M, Sarpel $Y$, Özbarlas S: Combined anterior and posterior fusions in spine surgery. $\mathrm{J}$ Turk Spinal Surg 7: 70-76, 1996

48. Gülşen M, Özkan C, Altın M: Lumbar transpedicular close wedge osteotomy for the treatment of kyphotic deformity due to ankylosing spondylitis. J Turk Spinal Surg 19: 397-406, 2008

49. Gülşen M, Özkan C, Kavak C: Anterior vs hybrid posterior instrumentation in the treatment of adolescent idiopathic scoliosis with Lenke type I curves. J Turk Spinal Surg 20: 9-22, 2009
50. Hamzaoğlu A, Tözün R, Kaygusuz MA, Seyhan F: İdiopatik skolyozun cerrahi tedavisinde Drummond ve Harri-Luque yöntemleri [The Drummond and Harri-Luque methods in the surgical treatment of idiopathic scoliosis]. 11. Milli Türk Ortopedi ve Travmatoloji kongresi, Ankara, 27-30 Eylül 1989, S: 310-312. (In Turkish)

51. Harrington PR: Treatment of scoliosis. Correction and internal fixation by spine instrumentation. J Bone Joint Surg Am 44-A: 591-610, 1962

52. Hibbs RA: An operation for progressive spinal deformities. NY Med J 93: 1013-1016, 1911

53. Hibbs RA, Risser JC, Ferguson AB: Scoliosis treated by the fusion operation: An end-result study of three hundred and sixty cases. J Bone Joint Surg Am. 13: 91-104, 1931

54. Hippocrates: On Joints. In: Withington ET, trans Volume III. Edited by: Capps E, Page TE, Rouse WHD. Hippocrates: The Loeb Classical Library. London: W. Heinemann, 200-397, 1927

55. İbişoğlu YU, Çalış FA, Yağızon A: İzmir ili Bornova İlçesi İlköğretim Kurumlarında Okuyan 12-14 Yaş Grubu Çocuklarda Skolyoz Prevalansı [The Prevalence of Scoliosis in 12-14 years old Children Studying at Primary Schools in the Bornova District of İzmir]. Türkiye Fiziksel Tıp ve Rehabilitasyon Dergisi 58: 109-113, 2012 (In Turkish)

56. Kabins MB, Weinstein JN: The history of vertebral screw and pedicle screw fixation. lowa Orthop J 11: 127-136, 1991

57. Kaplan H, Akyatan N, Kıral A, Kuşkucu M: Somatosensorial evok potansiyel yardımı ile skolyozda Drummond yöntemi uygulaması [Application of the Drummond method to scoliosis with the aid of somatosensory-evoked potential]. 11. Milli Türk Ortopedi ve Travmatoloji kongresi, Ankara, 27-30 Eylül 1989: 279-283(In Turkish)

58. Kaplan SÇ, Ekşi Ş, Bayri Y, Toktaş ZO, Konya D: Kyphectomy and pedicular screw fixation with posterior-only approach in pediatric patients with myelomeningocele. Pediatric Neurosurg 50:133-144, 2015

59. Kemal (M. Kemal Öke): Mal de pott, traité par l'operation D’Albee. Gazette Medicale d'Orient 70: 996, 1925 (In French)

60. Keskin D: Genç erkeklerde idiyopatik skolyoz görülme sıklığı [Prevalence of idiopathic scoliosis in young males]. Atatürk Üniversitesi Tıp Fakültesi Dergisi 30: 36-38, 1998 (In Turkish)

61. Kılınçer C, Şimşek O,Hamamcıoğlu MK, Çobanoğlu S: Lomber kifotik deformitenin diskektomi, fasetektomi, ve posterior osteotomi ile düzeltilmesi: olgu sunumu [Correction of lumbar kyphotic deformity through discectomy, facetectomy and posterior osteotomy: case presentation]. Türk Nöroşirürji Derneği 19. Bilimsel Kongresi, Kemer-Antalya, 27-31 Mayıs, 2005(In Turkish)

62. Lehnert-Schroth C: Skolyozun üç boyutlu tedavisi [Threedimensional treatment of scoliosis]. Çev.: Gülseren Kayalar. İstanbul: Pelikan Yayıncılık, 2013(In Turkish)

63. Luque ER: Segmental spinal instrumentation for correction of scoliosis. Clin Orthop Relat Res 163: 192-198, 1982

64. Marketos SG, Skiadas PK: Hippocrates; The father of spine surgery. Spine (Phila PA 1976) 24: 1381-1387, 1999

65. Marketos SG, Skiadas PK: Galen; A pioneer of spine research. Spine (Phila Pa 1976) 24: 2358-2362, 1999 
66. Mohan AL, Das K: History of surgery for the correction of spinal deformity. Neurosurg Focus 15: 1-5, 2003

67. Naderi S, Zileli M: Türkiye'de spinal füzyonun tarihi [History of spinal fusion in Turkey]. J Turk Spinal Surg 12: 54-59, 2001 (In Turkish)

68. Naderi S, Acar F, Arda MN: History of spinal disorders and cerrahiyetülhaniye: A review of a Turkish treatise written by Şerefeddin Sabuncuoğlu in 15th century. J neurosurgery: Spine 96: 352-356, 2002

69. Naderi S, Zileli M, Özer AF: Omurga cerrahisinin tarihçesi [History of spinal surgery]. İçinde: Zileli M, Özer AF (Ed). Omurilik ve omurga cerrahisi. İzmir, İntertıp Yayınevi, 2014: 3-16 (In Turkish)

70. Naderi S: Türkçe basılmış omurga-omurilik sağlığı ve hastalıkları ile ilgili eserler bibliyografisi [Bibliography of works on the spine-spinal health and diseases printed in Turkish]. J Turk Spinal Surg 26: 171-178, 2015 (In Turkish)

71. Oral İ, Özen N: Skolyoz. İstanbul: Yuva Yayınları, 2012 (In Turkish)

72. Oskay B: Mal de pott tedavisinde kemik aşıları [Bone grafts in the treatment of mal de pott]. Hastane 82:169-178, 1948 (In Turkish)

73. Ökten Ai, Gezercan Y, Çıkılı M, Arslan A, Uysal i, Boğa Z, Bilgin E, Olmaz B, Millet $\mathrm{H}$, Karaörs $\mathrm{H}$ : S2 alar iliak kanat vida ile spinopelvik stabilizasyon: Çoklu spinal füzyon ameliyatı sonrası kavşak (junctional) kifoz gelişen 7 olgu [Spinopelvic stabilisation using S2 alar iliac crest screw: 7 cases in which junctional kyphosis developed following multiple spinal fusion procedures]. Spinal deformiteler sempozyumu, Antalya, 29 Ekim-1 Kasım 2015 (In Turkish)

74. Ökten Ai, Gezercan Y, Arslan A, Menekşe G, Uysal I, Çıkılı M, Bilgin E: Spinal enstrüman cerrahisi sonrası farklı deformite gelişen hastalarda revizyon cerrahisi: 50 olgu [Revision surgery in patients developing various deformities following spinal instrumentation surgery: 50 cases]. Spinal deformiteler sempozyumu, Antalya, 29 Ekim-1 Kasım 2015 (In Turkish)

75. Özerdemoğlu RA, Yorgancıgil H, Deveci K, Yalçınkaya S: İlkokul öğrencilerinde ortopedik semptom ve deformite taraması [Screening for orthopaedic symptoms and deformities in primary school students]. Acta Orthop Traumatol Turc 30: 168-174, 1996 (In Turkish)

76. Öztürk C, Kirazlı Y, Akşit R: Skolyoz için okul taraması [School screenings for scoliosis]. Ege Tıp Derg 33: 45-48, 1994 (In Turkish)

77. Papadopoulos S: Quelques considerations sur la traitment de la scoliose par la gymnastique. Gazette medicale d'Orient 56: 16-23, 1911

78. Paşaoğlu A, Orhon C, Öktem S, Uzunoğlu H, Akdemir $\mathrm{H}$ : Torakolomber travmalarda cerrahi yaklaşım [Surgical approach to thoracolumbar traumas]. Türk Nöroşirurji Dergisi 1 (Ek 1): 104- 106, 1989 (In Turkish)

79. Risser JC: The application of body casts for the correction of scoliosis. Instr Course Lect. 12: 255-259, 1955
80. Roy-Camille R, Demeulenaere C: Ostheosynthese du rachis dorsal, lumbaire et lombosacree par plaque vissees dans les pedicles vertebraux et les apophyses articulaires. Presse Medicale 78: 1447-1448, 1970 (In French)

81. Selçuklu A, Paşaoğlu A, Akdemir H, Kurtsoy A, Erdoğan ZO: Spinal kırıklarda Harrington uygulamasının komplikasyonları [Complications of the Harrington application in spinal fractures]. Türk Nöroşirürji Dergisi 2: 61-63, 1991 (In Turkish)

82. Solak Ş, Benli T, Aydın E, Kış M, Tüzüner M, Akalıon S: Combined anterior and posterior surgery for the treatment of rigid idiopathic scoliosis. J Turk Spinal Surg 6: 5-7, 1995

83. Temoçin BO: Harrington metodu ile skolyoz tedavisinin üstünlüklerine dair klinik araştırma [Clinical research on the superiority of scoliosis treatment using the Harrington method]. Acta Orthop Tramatol Turc (Suppl 3): 61-79, 1978 (In Turkish)

84. Tezeren G, Özlü K, Aydemir A, Ayaşlı A, Kahraman Y, Dülgeroğlu D: School screening for scoliosis in Ankara. J Turk Spinal Surg 3: 92-94, 1993

85. Tiner $M$, Yücetürk G: Kliniğimizde Harrington çubukları ile tedavi edilmiş skolyoz vakalarının sonuçları [Results of the scoliosis cases treated at our clinic using Harrington rods]. 5. Türk Milli Ortopedi ve Travmatoloji Kongresi. Ankara, 19-21 Mayıs 1977, 383-387 (In Turkish)

86. Uğraş AA, Yılmaz M, Sungur I, Kaya I, Koyuncu Y, Çetinus ME: Prevalence of scoliosis and cost-effectiveness of screening in schools in Turkey. J Back Musculoskeletal Rehab 23: 45-48, 2010

87. Üzümcügül $\mathrm{O}$, Benli iT, Ofluoğlu E: Omurganın sagittal plan deformiteleri [Sagittal plane deformities of the spine]. Ankara, Türk Omurga Derneği Yayınları, 2016 (In Turkish)

88. Wieting J: Kongenitale Skoliose. In: Wieting. GülhaneFestschrift, Leipzig, Thieme, 1909 (In German)

89. Yaman O, Dalbayrak S: İdiopatik skolyoz [Idiopathic scoliosis]. Türk Nöroşirürji Dergisi 23 (ek 1): 37-51, 2013 (In Turkish)

90. Yaman O, Dalbayrak S: Kifoz. Tanı, gruplama ve tedavi yöntemleri [Kyphosis]. Türk Nöroșirürji Dergisi 23 (Ek 1): 6173, 2013 (In Turkish)

91. Yazıcı M: Non-Idiopathic Spine Deformities in Young Children. Springer. Berlin, Heidelberg, 2011

92. Yılmaz B, Ekşi MŞ, Işık S, Özcan Ekşi EE, Orkun Z, Toktaş A, Konya D: Magnetically controlled growing rod in early-onset scoliosis: A minimum of 2-year follow-up. Pediatric Neurosurg DOI: 10.1159/000448048, 2016

93. Yılmaz T, Gökçe A, Naderi S, Yaman O, Dalbayrak S: School screening of adolescent idiopathic scoliosis in 7928 Turkish children. J Turk Spinal Surg 27: 135-142, 2016

94. Zielke K, Stundait R, Beaujean F: Ventrale derotation spondylodese. Vorlaufiger Ergebnissbericht uber 26 operiete Faile. Arch Orthop Unfall-Chir 85: 257-277, 1976 (In German)

95. Zileli M: Surgery for kyphosis: Advances and Technical Standards in Neurosurgery, 41: 71-103, 2014 